\title{
PERANAN PSIKOLOGI DAN KONSELING DALAM PENINGKATAN KUALITAS SUMBER DAYA MANUSIA (SDM) MENUJU KESEJAHTERAAN MASYARAKAT EKONOMI ASEAN
}

\author{
(Oleh : Prof. Dr. Firman. MS. Kons Dosen Jurusan Bimbingan dan Konseling Fakultas IImu \\ Pendidikan Univesitas Negeri Padang) \\ Email : firman@konselor.org
}

\begin{abstract}
The implementation of ASEAN economic cooperation policy that is tagged along with the development of technology of information would apparently be savored by those having qualified human resource, and vise versa. The competencies required in that era include leadership capability, public speaking skill, foreign language proficiency, project design ability, negotiation and mediation skills, networking skill, and professionalism. Such competencies should be supported by adaptive and responsive human resource that has capability in technology. Psychology and Counseling are needed in the plan and the implementation of human resource development, and in dealing with the potential impacts that are likely to arise. For years, to develop human resource, Psychology and Counseling have been used for assessing, recruiting and selecting, consulting, individual and group counseling, training and other relevant activities. Essentially, Psychology and Counseling could be widely used to intervene the development of human resource to create social welfare.
\end{abstract}

\section{A. Pendahuluan}

Dewasa ini perubahan sosial budaya sedang dijalani masyarakat dari berbagai belahan dunia, yang ditunjukan oleh kemajuan berbagai kegiatan teknologi, informasi dan komunikasi dalam berbagai bidang kehidupan. Perubahan tersebut membawa kemajuan peradaban manusia berinteraksi satu dengan lainnya dalam menyelesai berbagai persoalan untuk memenuhi keperluan hidup. Masyarakat satu daerah ke daerah lain dengan cepat dapat berkomunikasi untuk memperoleh informasi, layanan jasa dan barang melalui internet.

Berbagai aktifitas layananan kantor/bank, penjualan jasa/barang berorientasi kertas beralih ke on line. Kesejahteraan, kebahagian serta pertumbuhan ekonomi meningkat beriringan dengan kemajuan industrialisasi, yang ditandai produktifitas semakin bertambah. Perempuan selama ini bekerja di sektor domestik, semakin meningkat untuk bekerja dalam kehidupan publik. Keterlibatan perempuan di sektor 
publik ditandai dengan semakin banyaknya perempuan bekerja di parlemen, pemeritahan, perdagangan, dan industri. Persaingan dengan kompetensi unggul dalam mewujudkan impian dan harapan menuntut Sumber Daya Manusia (SDM) yang memiliki disiplin dan tangguh menghadapi persoalan.

Kemajuan teknologi informasi menimbulkan kesadaran baru masyarakat sehingga mendorong terbentuknya kerjasama ekonomi kawasan, seperti Masyarakat Ekonomi Asean (MEA). Kerjasama ekonomi Asean merupakan kebutuhan masyarakat untuk bermitraan dalam memenuhi kepentingkan bersama dengan mensukseskan kerjasama multilateral. Kerjasama multilateral diarahkan untuk meningkatkan pertumbuhan dan pembangunan, mengatasi tantangan global, diantaranya ketahanan pangan dan energi, perubahan iklim dan stabilitas keuangan internasional. Pada gilirannnya kerjasama multilateral diharapkan meningkatkan kesejahteraan masyarakat negara anggota Asean.

Kerjasama ekonomi Asean dan perkembangan teknologi informasi diprediksi akan memicu meningkatnya kelas menengah baru dengan kemampuan, keterampilan dan gaya hidup berbeda dengan kelas yang sama di Negara-negara Barat. Pengembangan SDM masing-masing negara semakin meningkat dipicu terjadinya perubahan pola relasi guru dengan peserta didik di lingkungan pendidikan. Guru bukan satu-satunya sumber pembelajaran tetapi berperan sebagai fasilitor dan motivator. Penggunaan strategi pembelajaran berorientsi peserta didik (student centred learning) semakin berkembang dengan memberi kesempatan kepada peserta didik mengali berbagai sumber pembelajaran berbantuan teknologi informasi. Sistim pembelajaran dari ruangan kelas yang terikat waktu bersifat tatap muka beralih ke on line. Temuan baru berupa perangkat mesin-mesin otomatis akan mengantikan pekerjaan yang memerlukan banyak orang, yang selama ini menggunakan tenaga, waktu dan sistem yang sangat komplek menjadi sederhana. Pemikiran masyarakat Asean semakin berkembang dalam berbagai bidang, ditunjukan oleh kemampuan mengumpulakan informasi dari berbagai sumber serta berjejaring dengan berbagai orang yang memiliki kekuatan berbeda antar negara dalam membangun kekuatan diri sendiri atau kelompok masyarakat.

Kemajuan teknologi informasi dalam pasar tunggal Asean akan dirasakan manfaatnya untuk kemajuan dan kesejahteraan masyarakat. Penyalahgunaan kemajuan teknologi informasi untuk kepentingan yang menjurus kehancuran dan merorong kesejahteraan serta kemajuan masyarakat Asean akan ditemui sebagai dampak negatif 
perubahan. Penyalah gunaan perkembangan teknologi informasi dan komunikasi, selama ini, diantaranya jejaringan teroris, penipuan/perampokan, perjudian serta prostitusi dan sebagainya. Website institusi perbankan/pemerintah/pendidikan kadang kala dibobol oleh orang-orang yang tidak bertanggungjawab. Kerahasiaan informasi, data dan dokumen yang ada, sulit dibendung dan tidak jarang disalah gunakan untuk kepentingan pribadi dan sekelompok orang. Informasi yang tidak jelas kebenaranya dan kadang kala bersifat mengasut atau mencemarkan nama baik orang lain tidak jarang menyebar di lingkungan masyarakat.

Kondisi tersebut menyebabkan konflik, kecemasan, kerusakan perangkat komputer akibat serangan virus, kehilangan berbagai file data dan kerusakan modem internet, akan merorong kesejahteraan masyarakat Asean. Kerjasama multilateral tersebut akan memberi peluang kesempatan kerjas baru. Persaingan kerja semakin meningkat dengan keahlian dan keterampilan sesuai dengan kualifikasi tenaga yang dibutuhkan masyarakat Asean, yang berakibat kepada pemutusan hubungan kerja (PHK) bagi tenaga kerja yang tidak memenuhi standar yang diharapkan. Pendidikan yang diperlukan dunia kerja mengarah kepada kemampuan mentransformasikan pengetahuan dan keterampilan bersifat profesional sesuai dengan tuntutan masyarakat Asean yang sedang berubah. Pekerjaan yang selama ini dipandang sebagai pemberi jasa pelayanan berubah menjadi produk komuditi dengan standar yang diharapkan. Tenaga kerja yang belum memenuhi standar akan terpinggirkan sehingga menyebabkan pengangguran semakin meningkat bagi negara-negara yang memiliki kualitas SDM yang tidak menguntungkan.

Persaingan SDM satu negara dengan negara lain di Asean semakin ketat. Apabila suatu negara mengalami kegagalan melahirkan SDM berkualitas akan menimbulkan kefrustasian yang tidak jarang melahirkan kemunduran generasi, yang ditunjukan oleh berbagai masalah, diantaranya : kemerosotan moral, kehidupan konsumtif dan boros, korupsi, manipulasi dan menghalalkan berbagai cara untuk mencapai tujuan pribadi. Masyarakat akan semakin gelisah karena kenakalan remaja dan perilaku menyimpang semakin meningkat serta penyebaran penyakit menular HIV/AID atau penyakit lainnya. Kewibawaan pemimpin tradisional semakin melemah, modal sosial yang dapat dimanfaatkan untuk kesejateraan bersama, seperti gotong royong dan saling tolong menolong mulai ditinggalkan. Pola interaksi masyarakat dengan adanya temuan baru 
berupa telepon celular dan komputer dari tatap mula ke telepon/on line. Kedekatan hubungan secara tatap muka telah beralih ke dunia maya melalui berbagai jejaringan sosial dan kesadaran kolektif dengan rasa kebangsaan mulai luntur. Sebagian besar orang disibukan dengan dunia mereka sendiri bersama komputer/HP yang mereka miliki, walaupun berada dalam kebersamaan dengan orang lain. Pola tingkah laku masyarakat timur dengan sopan santun dan saling harga menghargai, sebagian sudah ditinggalkan dengan pola hidup praktis dan efektif. Kondisi ini tidak jarang membawa berbagai persoalan yang menimbulkan keresahan dan kerugian material yang tidak ternilai harganya di lingkungan masyarakat Asean kelak, bila pelakuan kebijakan kerjasama ekonomi Asean tidak dicermati dengan baik.

Peran teknologi informasi dan komunikasi di era ekonomi Asean akan mewujudkan kesejahteraan dan kebahagian hidup masyarakat tidak dapat dihindari. Kemajuan teknologi dipandang sebagai kekuatan menopang gaya hidup masyarakat Asean sesuai dengan perkembangan ilmu pengetahuan dan teknologi serta kehidupan sosial di era globalisasi. Masyarakat Asean yang memiliki kemampuan dan keterampian yang rendah cenderung tergantung dan tidak dapat memetik keuntungan dengan perkembangan kerjasama multilateral tersebut. Begitu pula sebaliknya bagi masyarakat yang memiliki kemampuan dan keterampilan akan memetik banyak manfaat untuk kesejahteraan dan kebahagiaan hidup di era ekonomi Asean. Kondisi ini akan memicu terjadi kesenjangan antar golongan, selanjutnya apabila tidak ditanggani dengan baik akan menimbulkan masalah sosial baru di masyarakat.

Teknologi informasi merupakan salah satu sarana pendukung yang digerakan oleh manusia sebagai pengguna sesuai dengan keperluan masing-masing. Pemanfaatan teknologi informasi dengan baik dalam kerjasama ekonomi Asean, akan dapat meningkatkan kemajuan dan kesejahteraan masyarakat berpartisipasi dalam pasar tunggal tersebut, begitu pula sebaliknya. Pemanfaatan kemajuan teknologi informasi di lingkungan masyarakat Asean, ditentukan oleh orang dengan kopetensi dan kualitas yang dimilikinya. Pengembangan Sumber Daya Manusia (SDM) berkualitas, yang pada gilirannya dapat menyadari penyalahgunaan media teknologi informasi akan merusak sendi-sendi kehidupan masyarakat di era kerjasama ekonomi Asean dalam mewujudkan kesejahteraan dan kebahagiaannya. Paparan berikut akan membahas bagaimana peran psikologi dan konseling dalam peningkatan Sumber Daya Manusia (SDM) menuju 
kesejahteraan Hidup Masyarakat Asean. Pengungkapan permasalahan ini bermanfaat guna merencanakan, melaksanakan program pembangunan SDM beserta dampak yang akan ditimbulkan dengan diberlakukannya kerjasama ekonomi Asean.

\section{B. Pengembangan Sumber Daya Manusia (SDM) dan Kesejahteraan Masyarakat Asean}

Perkembangan teknologi informasi telah membawa berbagai manfaat dalam kehidupan masyarakat. Pekerjaan yang selama ini memerlukan biaya, tenaga dan waktu yang cukup banyak dapat diefektifkan dengan perkembangan teknologi informasi. Informasi dari satu tempat ke tempat lain dengan mudah dapat diterima. Pengembangan Sumber Daya Manusia (SDM) pada suatu negara dapat dilakukan dengan berbagai alternatif dengan sistem on line. Kondisi ini akan menghilangkan hambatan dari segi tempat, tenaga, waktu, biaya serta sarana pendukung lainnya.

Pengembangan kualitas SDM merupakan kegiatan dalam menyiapkan manusia untuk memiliki pengetahuan, keterampilan dan sikap kerja yang membuahkan kebahagiaan diri sendiri serta masyarakat sekitarnya. SDM yang berkualitas akan menikmati kehidupan sosial ekonomi yang layak, ditandai oleh kesehatan, kebersamaan dan kepuasan, memperoleh penghasilan yang layak sebagai penentu kebahagian yang dirasakannya.

Masyarakat yang kurang memiliki pendidikan cenderung tidak mempunyai kemampuan menghasilkan kegiatan produktif, akan memberi menyumbang semakin meningkatnya kemiskinan suatu negara. Berbagai strategi dan pendekatan pengembangan SDM melalui pendidikan/pelatihan/penataran/worshop, bea siswa, perubahan sistem organisasi, pengucuran dana bantuan dan kebijakan pemberdayaan telah dilakukan pemerintah untuk mengatasi kemiskinan. Pengembangan SDM suatu negara ditujukan untuk meningkatkan produktifitas dan efesiensi kerja, yang menghidari kerusakan dan kecelakaaan serta bertingkah laku yang dapat memberikan pelayan dengan baik kepada masyarakat pengguna.

Lako dan Sumaryati (2002 https://www.linkedin.com/pulse/kompetensi-sdm-jadikebutuhan-mawardi-s-t) mengemukakan SDM yang berkualitas memiliki empat karakter, yaitu: (1) memiliki competence (pengetahuan, keterampilan, sikap perilaku) yang memadai; (2) commitment terhadap organisasi; (3) selalu bertindak secara cost- 
efectiveness dalam setiap aktivitasnya; dan (4) congruence of goals, yaitu bertindak sesuai dengan tujuan organisasi perusahaan. SDM yang berkualitas merupakan sumber keunggulan kompetitif (competitive advantage) untuk meningkatkan keunggulan bersaing suatu masyarakat.

Pengembangan SDM berbasis kompetensi merupakan salah satu strategi pemerintah dalam mengatasi kemiskinan. Berbagai program diluncurkan pemerintah Indonesia dalam mengatasi kemiskinan, diantaranya : wajib belajar 9 tahun, pemberian bea siswa, Indonesia Sehat, Indonesia mendidik, worshop dan sebagainya. Mawardi (https://www.linkedin.com/pulse/kompetensi-sdm-jadi-kebutuhan-mawardi-s-t) menjelaskan Sumber Daya Manusia kompeten memiliki kemampuan dalam aspek pengetahuan (knowledge, science), keterampilan (skill, technology), dan sikap perilaku (attidude) yang dibutuhkan menunjang keberhasilan pelaksanaan pekerjaan.

Peningkatan kapasitas pengembangan SDM menghadapi Masyarakat Ekonomi Asean (MEA) ditujukan untuk meningkatkan potensi individu, masyarakat/organisasi dengan stuktur organisasi, mekanisme kerja, prosedur mengambil keputusan, penyiapan sarana prasarana pendukung dan jaringan organisasi. Persaingan di era pasar tunggal MEA ditentukan oleh kemampuan masyarakat berkompetisi berbasis mutu diantara masyarakat lainnya. Kompetensi individu akan terlihat dari kemampuan menyesuaikan diri serta tanggung jawab yang dihasilkan dari suatu pekerjaan. Pemberlakuan kebijakan Masyarakat Ekonomi Asean (MEA) akan mewujudkan pasar tunggal, kawasan ekonomi produktif, wilayah pembangunan ekonomi merata dengan daerah terintegrasi dalam ekonomi global. Kopetensi yang dimiliki masyarakat sangat menentukan untuk mengapai peluang mewujudkan kesejahteraan serta kebahagiaan yang diidam-idamkannya.

Kualitas SDM merupakan faktor penentu keberhasilan dalam pewujudan kesejahteraan dan kebahagian hidup masyarakat di era pasar tunggal Asean. Kemampuan daya saing masyarakat harus ditingkatkan untuk memanfaatkan perkembangan teknologi dengan baik sehingga pada gilirannya dapat meningkatkan produktifitas kerja. Berbagai kemampuan harus dimiliki masyarakat dalam situasi pergaulan global, diantaranya kemampuan kepemimpinan, public speaking, bahasa asing, kemampuan merancang proyek, negosiasi dan mediasi, networking, dan profesinalisme. Penguasaan kemampuan tersebut berguna untuk beradaptasi dengan lingkungan untuk mewujudkan impian dan cita-cita yang diharapkan. Keberagaman kompetensi 
masyarakat dalam menghadapi ekonomi Asean, melahirkan persepsi yang berbeda terhadap pasar tunggal Asean.

Berdasarkan hasil penelitian Personal Growth

(2016)

(http://rubik.okezone.com/read/25125/menghadapi-masyarakat-ekonomi-ase)

mengungkapkan sebanyak 43\% responden berpandangan Masyarakat Ekonomi Asean (MEA) sebagai peluang dan tantangan berusaha/berkarir, 32\% responden Masyarakat Ekonomi Asean (MEA) merupakan peluang; 20\% responden menganggap Masyarakat Ekonomi Asean (MEA) sebagai tantangan; dan 5\% responden menganggap Masyarakat Ekonomi Asean (MEA) tidak hanya sebagai peluang dan tantangan, tetapi juga hambatan.

Peningkatan SDM secara berkelanjutan diperlukan dalam menghadapi persaingan secara individu maupun kelompok di era Masyarakat Eknomi Asean. Peningkatan kompetensi SDM harus dilakukan secara proaktif sehingga terbentuk pribadi-pribadi yang $\begin{array}{lllll}\text { mau belajar dan } & \text { bekerja }\end{array}$ https://apioindonesia.files.wordpress.com/2010/06/makalah-05_57_64-tekad-wahyon) menjelaskan SDM yang diperlukan di pada era globalisasi ini adalah SDM yang sanggup menguasai teknologi dengan cepat, adaptif dan responsif terhadap perubahanperubahan teknologi. Masyarakat yang kurang dapat menangkap peluang dan menganggap pekerjaan sebagai beban serta tidak memanfaatkan waktu dengan baik, meggambarkan etos kerja rendah, menjadi hambatan dalam pewujudan kesejahteraan masyarakat di era pasar tunggal Asean.

Dengan demikian dapat disimpulkan penyiapan SDM yang berkualitas berkelanjutan untuk ikut berpartisipasi dalam ekonomi masyarakat Asean sangat diperlukan. Penyiapan memlukan berbagai stategi dengan menggunakan pendekatan psikologi dan konseling guna penyiapan sumber daya manusia berkualitas. SDM berkualitas merupakan energi menggerakan masyarakat untuk tujuan produksi dan jasa. Sedangkan sumber daya yang berkarakter ditunjukan oleh kepribadian masyarakat yang teguh melaksanakan aturan, mempunyai kepekaan sosial, serta dapat mengatasi konflik sosial dengan lingkungan. SDM berkualitas dan berkarakter akan memberikan sumbangan dalam peningkatan kesejahteraan dan kebahagian masyarakat di era ekonomi Asean. 


\section{PERAN PSIKOLOGI DAN KONSELING DALAM PENINGKATAN KUALITAS SDM MENUJU KESEJAHTERAAN MASYARAKAT}

Perwujudan kebijakan Masyarakat Eknomi Asean (MEA) merupakan salah satu intervensi dalam peningkatan kesejahteraan masyarakat dalam kehidupan sosial dan psikologi. Kesejahteraan psikologis masyarakat merupakan peningkatan kualitas mental dalam menjalani kehidupannya. Ryff (1989) dan Singer (1996) menjelaskan masyarakat yang memiliki kesejahteraan psikologis, ditunjukan oleh kemampuan merealisasikan potensi diri secara berkesinambungan, menerima diri apa adanya, mampu menjalin hubungan secara baik dengan orang lain, memiliki kemandirian dan arti hidup serta mampu mengontrol lingkungan. Sedangkan kesejahteraan sosial menurut Midgley (2000: xi) merupakan kehidupan manusia yang aman dan bahagia, disebabkan oleh terpenuhinya gizi, kesehatan, pendidikan, tempat tinggal, serta mendapatkan perlindungan dari resiko-resiko yang mengancam kehidupannya. Kesejahteraan masyarakat di era Masyarakat Ekonomi Asean (MEA) ditentukan kualitas Sumber Daya Manusia masyarakat itu sendiri. Berbagai kebijakan telah dilakukan oleh negara-negara ekonomi Asean dalam pengembangan SDMnya.

Sejak psikologi berdiri sebagai salah satu cabang ilmu dan konseling menerapkannya dalam pemberian layanan terhadap individu, kelompok serta masyarakat telah banyak memberikan sumbangan untuk perkembangan Sumber Daya Manusia di berbagai negara. Konsep, teori, teknik dan hasil penelitian berkaitan dengan tingkah laku manusia sebagai kajian dari psikologi, telah dijadikan sebagai acuan perencanaan, pelaksanaan, evaluasi dan tindak lanjut pembangunan SDM.

Psikologi merupakan induk dari ilmu yang diterapan dalam konseling. Oleh karena itu psikologi dengan konseling tidak bisa dipisahkan dalam praktek peningkatan kualitas SDM di lingkungan masyarakat ekonomi Asean. Pengunaan psikologi dan konseling dalam pengembangan SDM dapat dijadikan sarana efektif pencapaian tujuan yang diinginkan dalam pembangunan masyarakat Asean menuju perubahan ke arah kemajuan. Sumbangan psikologi dan konseling semakin dirasakan dalam perumusan perencanaan, pengambilan kebijakan serta memperkirakan dan mengatasi permasalahan beserta dampak dari pembangunan tersebut. Pewujudan kegiatan pemberdayaan SDM telah dilakukan melalui berbagai kegiatan, antara lain : (1) asesmen individual dan 
organisasi, (2) rekrutmen dan seleksi, (3) konsultasi, konseling individual dan kelompok, (4) training dan sebagainya.

Asesmen selama ini dilakukan untuk individual dan organisasi. Asesmen individual merupakan kegiatan memetakan serta mendiskripsikan potensi individu, yang berguna untuk meprediksi penempatan, penyaluran dan pengembangan dalam bidang pekerjaan tertentu. Kegiatan asesmen berguna membantu individu yang sedang mengalami permasalahan dalam penyaluran potensi yang dimilikinya, untuk mewujudkan kebahagian dan kesejahteraan kehidupan pribadi dan lingkungan. Berdasarkan asesmen tersebut individu akan mendapatkan pelayanan dalam upaya peningkatan kualitas diri secara optimal, baik dilakukan secara kelompok maupun individual. Di samping asesmen individul, pemerintah dan lembaga pemberdayaan sumber daya manusia juga melakukan asesmen organisasi menggunakan pendekatan psikologis. Sedangkan asesemen organisasi yang dilakukan selama ini, antara lain : (1) asesmen jabatan, (2) asesmen kompetensi, (3) analisis beban kerja

Kegiatan lain yang dilakukan dalam pengembangan SDM menggunakan pendekatan psikologis dan konseling, yaitu rekrutmen dan seleksi. Rekrutmen merupakan kegiatan penarikan sekelompok calon pencari kerja berkeinginan bergabung untuk mengeluarkan seluruh potensi diri untuk berkontribusi mengisi posisi yang tersedia dalam suatu organisasi. Rekrutmen ditujukan untuk: (1) mencari bakat/potensi pelamar yang diperlukan, (2) memotivasi pencari kerja mengeluarkan kemampuannya untuk mendapatkan pekerjaan tersebut dan (3) mengisi kekosongan posisi/jabatan dalam organisasi. Rekrutmen dapat diklasifikasikan atas : (1) rekrutmen internal, pengisian posisi lowongan berkaitan dengan jenjang karir, promosi jabatan, demosi atau pemberian jabatan ke tingkat yang lebih rendah dan mutasi, (2) rekrutmen eksternal, pemilihan dan perekrutan diserahkan kepada pihak luar, seperti yayasan tenaga kerja, konsultan dan biro latihan ketenaga kerjaan. Permasalahan yang dialami individu, kelompok dan masyarakat sering dilakukan konsultasi, konseling individual, kelompok dan klasikal menggunakan pendekatan psikologi dan konseling.

Penggunaan psikologi dan konseling dalam perencanaan, pelaksanaan serta dampak atas suatu pembangunan belum termanfaatan secara optimal. Perencanaan dan pelaksanaan pembangunan berhubungan dengan manusia sebagai sasarannya. Sehubungan dengan hal itu pemanfaatan konsep, teori, pendekatan psikologi sangat 
diperlukan guna mencapai efektifitas dan efesien pembangunan. Psikologi dan konseling memerlukan ilmu lain untuk memahami individu, kelompok dan masyarakat menuju kesejahteraan masyarakat Asean. Kolaborasi dan kerjasama antar pakar ilmu serumpun sangat diperlukan dalam pembangunan SDM di era pasar tunggal Asean.

\section{Kesimpulan}

Berdasarkan uraian tersebut di atas, dapat disimpulkan hal sebagai berikut :

1. Sumber Daya Manusia (SDM) di era Masyarakat Ekonomi Asean (MEA) diharapkan memiliki kepemimpinan, kemampuan public speaking, bahasa asing, merancang proyek, negosiasi dan mediasi, networking, dan profesinalisme. Kopetensi tersebut harus didukung oleh peguasaan teknologi, adaptif dan responsif terhadap perubahanperubahan yang ada. Penguasaan kemampuan tersebut akan melahirkan SDM berkualitas dan berkarakter sesuai dengan standar yang diharapkan masyarakat di era kerjasama ekonomi Asean.

2. Psikologi dan konseling diperlukan dalam proses perencanaan, pelaksanaan pembangunan Sumber Daya Manusia beserta dampak yang akan terjadi. Pemanfaatan psikologi dan konseling dalam pengembangan Sumber Daya Manusia (SDM) selama ini digunakan untuk asesmen individual dan organisasi, rekrutmen dan seleksi, konsultasi, konseling individual dan kelompok, serta training dan sebagainya. 


\section{Daftar Kepustakaan}

Gilley, J.W. \& Maycunich, A.(2000), Beyond the Learning Organization, Harper Collins Publishers, USA Kuntjoro. peranan psikologi dalam pembangunan: sebuah bidang garapan psikologi yang terlupakan. Buletin Psikologi, Tahun XI, No. 1, Juni 2003

Marr, Benard Marr, (2016) 5 Things Everyone Should Know About Machine Learning And Al. https://www.linkedin.com/pulse/kompetensi-sdm-jadi-kebutuhan-mawardi-s-t) Diakses tanggal 10 Oktober 2016.

Mulinge, M., \& Mueller, C. W. (1998). Employee job satisfaction in developing countries: The case of Kenya. World Development, 26, 2181-2199.

Personal Growth (2016), Menghadapi Masyarakat Ekonomi ASEAN (MEA): Meningkatkan Kualitas Diri di Pasar International. (http://rubik.okezone.com/read/25125/menghadapi-masyarakatekonomi-ase)

Ryff (1989) dan Singer (1996). Ryff, C. D., \& Keyes, C. L. M. (1995). The structure of psychological well-being revisited. Journal of Personality and Social Psychology, 69(4), 719-727.

Ryff, C. D., \& Singer, B. (2005). From social structure to biology: Integrative science in pursuit of human health and well-being. In C. R. Snyder, \& Lopez (Eds.), Handbook of positive psychology (pp. 541-553). New York: Oxford University Press.

Wright, T. A., Cropanzano, R., \& Bonett, D. G. (2007). The moderating role of employee positive well being on the relation between job satisfaction and job performance. Journal of Occupational Health Psychology, 12, 93-104. 